Article Title: Emotions and the British Government's Decision for War in 1914 Author: John W. Young.

Address: Dept. of History, University of Nottingham,

\begin{abstract}
Recent years have witnessed increasing interest among international historians in the impact of emotions on foreign policy decisions, as part of a broader movement usually known as the 'emotional turn.' This is associated with findings, from the field of neuroscience, that cognition and emotion - rather than operating independently are inextricably bound together in human decision-making Most work thus far has concentrated on American foreign policy since 1945, but this article broadens the focus to consider the impact of emotions on British decision-makers, especially Cabinet ministers, as they debated whether to go to war in 1914. It shows that, despite a tendency by the protagonists themselves to interpret their actions in rational terms, sufficient evidence of emotions can be found in the written record to allow a fresh approach to be taken to the July Crisis. While emotions must be seen as acting alongside rational mental processes, rather than regularly overpowering them, a focus on the subject helps explain different approaches taken by individual ministers, why the majority came to approve intervention in the conflict and how the Prime Minister, H. H. Asquith, partly by appearing to control his feelings, minimised resignations over the fateful decision. It also allows a new view to be taken of why the Cabinet decided to go to war on 4 August in defence of Belgium, despite deciding just a few days earlier that the question of fulfilling the 1839 guarantee of Belgian neutrality was 'one of policy than of legal obligation.'
\end{abstract}




\section{Emotions and the British Government's Decision for War in 1914}

\section{John W. Young}

Recent years have witnessed interest among some international historians in the impact of emotions on policy. This is part of a broader movement, the so-called 'emotional turn', that has impacted on a range of disciplines. It is encouraged by neuroscientific findings that cognition and emotion - rather than operating independently - are inextricably linked in the brain's decision-making, a process one article has dubbed 'cogmotion.' ${ }^{1}$ While individuals might believe they take decisions after carefully weighing options, the fact is that powerful feelings - like anger, fear, hope, resentment - also shape their choices. The argument is that, rather than dismissing them as irrational and primitive, 'By studying emotions, we can find out much more about human motives, about what triggers actions..., about what influences decisions... ${ }^{, 2}$ Given that emotions are integral to decision-making, they cannot simply be ignored. This is not to say that emotions outweigh rational thinking, though in certain in certain, critical situations they might - as when fear leads someone to jump away from a snake. Rather, as decisions are considered, emotions and reason will interact. ${ }^{3}$

Unless otherwise stated, all dates in the footnotes are to the year 1914.

${ }^{1}$ Douglas Barnett and Hilary Ratner, 'The Organization and Integration of Cognition and Emotion in Development', Journal of Experimental Child Psychology, No. 67 (1997), 303-16.

${ }^{2}$ Ute Frevert, in Forum, 'History of Emotions', German History, Vol.28, No.1 (2010), 68. For introductions to the 'emotional turn' in History: Nicole Eustace et al, 'AHR Conversation: the Historical Study of Emotions', American Historical Review, Vol. 117, No. 5 (Dec. 2012), 1487-1530; Jan Plamper, The History of Emotions (Oxford: Oxford University Press, 2015).

${ }^{3}$ See Carroll Izard, 'Emotion Theory and Research', Annual Review of Psychology, Vol. 60 (2009), 58 . 
Frank Costigliola, the leading figure in the field of emotions and international history, has demonstrated how the emotions of key officials, like George Kennan, helped sour US-Soviet relations at the dawn of the Cold War. William Leogrande concludes that, in 1959-60, 'the intense emotional response of US policymakers to Fidel Castro's anti-American rhetoric led them to conclude that co-existence with [Cuba's] revolutionary government was impossible, even before Castro took policy decisions that seriously threatened US interests.' And Barbara Keys points out that, although Secretary of State Henry Kissinger posed as an arch-realist, he was also given to temper tantrums, jealousy and self-doubt; his sense of 'betrayal' by Moscow may have contributed to US-Soviet confrontation during the 1973 Middle East War. ${ }^{4}$ This article considers the possible impact of emotions on British decision-makers during the July Crisis, especially Cabinet ministers. The views of civil servants, especially in the Foreign Office, were also influential in decision-making, but they tended to favour intervention in the First World war, whereas there was intense debate between ministers, in whose hands the final decision lay.

Emotion may be defined as a 'strong feeling' or an 'intuitive feeling as distinguished from reasoning or knowledge. ${ }^{5}$ Emotions are more powerfully felt than longer-terms 'moods' and may lead to rapid decision-making, based on 'gut' instincts. They 'typically arise when one evaluates an event or outcome as relevant for one's concerns or preferences... One cannot simply choose to have or not have

\footnotetext{
${ }^{4}$ Frank Costigliola, 'After Roosevelt's Death: dangerous emotions, divisive discourses and the abandoned alliance', Diplomatic History, Vol. 34, No.1 (2010), 1-23; William Leogrande, 'Anger, antiAmericanism and the break in U.S.-Cuban relations', Diplomatic History, Vol. 41, No.1 (2017), 105; Barbara Keys, 'Henry Kissinger: the emotional statesman', Diplomatic History, Vol. 35, No. 4 (2011), 587-609.

${ }^{5}$ https://en.oxforddictionaries.com/definition/emotion (accessed 23 June 2017).
} 
emotions... ${ }^{6}$ It will be argued, here, that focusing on them helps explain different approaches taken by individual ministers, how the majority came to approve intervention in the war and how the Prime Minister, H. H. Asquith, minimised resignations over that fateful decision. Ultimately, emotions should be blended with work on 'rational' decision-making, to reflect the fact that both form part of human decision-making, but here the focus is on the former, because they have not previously been treated seriously and their potential significance deserves to be emphasised. The article will begin by showing how almost all existing accounts, not only by academics, but also by policy-makers themselves, see the decision for war in rational terms. But it then argues that, while decision-makers interpreted their own actions in rational terms, references to emotions seep into the written record with surprising frequency, not least because ministers were under immense psychological strain as war approached. It goes on to show how such an emotional atmosphere impacted on the course of events: how special respect was given to leading ministers who demonstrated strong emotional control, including Asquith and the Foreign Secretary, Sir Edward Grey; how emotionally-charged appeals to honour and loyalty helped minimise resignations from the government over the eventual decision for war; and how rising anger over German behaviour helped push the Cabinet to go to war in defence of Belgian neutrality.

\section{The Primacy of Rationalism}

Emotions have been mentioned in previous accounts of the 1914 crisis. In the early twentieth century, one analyst recognised, 'the danger of war proceeds mainly from

\footnotetext{
${ }^{6}$ Marcel Zeelenberg et al, 'On emotion specificity in decision making', Judgment and Decision Making, Vol. 3, No. 1 (2008), 20.
} 
the temper of the people, which, when aroused, disregards self-interest...'7 and there is a persistent idea that emotions mattered at a popular level. Thus, it has been said Germany's invasion of Belgium 'proved to be a catalyst which unleashed the many emotions, rationalisation and glorifications of war which had long been part of the British climate of opinion. ${ }^{\text {8 }}$ Detailed studies of 'war enthusiasm' in 1914, however, have concluded that this phenomenon has been exaggerated. ${ }^{9}$ Where elite policymakers are concerned comments on emotion tend to be in passing remarks, like Pierre Renouvin's belief that Germany's ‘violation of Belgian neutrality produced in... English people the wave of emotion which made... intervention possible', or Christopher Clark's recognition that, in Cabinet on 2 August, Grey, declared 'with great emotion that Britain had a moral obligation to support France...'10

Aside from some recent works (discussed below) on the concept of 'honour', however, such remarks are not followed by sustained analysis of emotions. Instead, these are treated as a short-term disturbance to 'normal', rational thinking, as with the assertion that, in Austria-Hungary, following the assassination of Archduke Franz Ferdinand, which sparked the crisis, 'Once the shock had subsided... actions were once again based on deliberation...' or Clark's comment that, 'with emotions running high' in early August, there was 'a heightening and polarization of utterance that may

\footnotetext{
${ }^{7}$ Alfred Thayer Mahan (1912), quoted in M.S. Anderson, The Rise of Modern Diplomacy, 1450-1919 (London: Longman, 1993), 277.

${ }^{8}$ Zara Steiner and Keith Neilson, Britain and the Origins of the First World War (Second edition, Basingstoke: Palgrave, 2003), 248.

${ }^{9}$ For example, Jeffrey Verhey, The Spirit of 1914: militarism, myth and mobilization in Germany (Cambridge University Press, 2000); Michael Neiberg, Dance of the Furies: Europe and the outbreak of World War One (Cambridge, MA: Harvard University Press, 2011); Catriona Pennell, A Kingdom United: popular responses to the outbreak of the First World War in Britain and Ireland (Oxford University Press, 2012).

${ }^{10}$ Pierre Renouvin, The Immediate Origins of the War (New Haven: Yale University Press, 1928), 298.; Christopher Clark, The Sleepwalkers: how Europe went to war in 1914 (London: Penguin, 2013), 543.
} 
lead us to misread the underlying realities of the situation.' ${ }^{11}$ A rare exception is William Jannen who, in a 1983 essay, paid attention to 'accumulating stress and fears' in Austria before Sarajevo and discussed 'emotional posture', but his primary focus was on psychological influences. ${ }^{12}$ In the international relations literature, too, rational actor models have dismissed emotional factors. Analysing outbreaks of wars in 1941, Theodore Abel rather arrogantly insisted that, 'The decision to fight... is based upon a careful weighing of chances... In no case is the decision precipitated by emotional tensions...' (italics added). In 1965, Ole Holsti discussed the effect of stress upon policy-makers in 1914, yet barely mentioned emotions. A generation later, Jack Levy judged the war was caused by 'the underlying international and domestic forces which shaped the preferences of the great powers... ${ }^{, 13}$

One difficulty for researchers is that policy-makers themselves have usually assumed that 'thinking' is more important than 'feeling' and, therefore, defend their actions on rational grounds in their correspondence, diaries and memoirs. Among British ministers reluctantly won over to war in 1914, Charles Hobhouse, the Postmaster-General, claimed he 'did not want Germany to destroy us in detail as I believe she hoped to do'; Walter Runciman, President of the Board of Agriculture, believed 'we could not tolerate the German fleet in the English Channel'; and Reginald McKenna, the Home Secretary, had 'no doubt... we were committed to

\footnotetext{
${ }^{11}$ Manfred Rauchensteiner, The First World War and the End of the Habsburg Monarchy (Vienna: Böhlau Verlag, 2014), 90; Clark, Sleepwalkers, 541.

${ }^{12}$ William Jannen, 'The Austro-Hungarian Decision for War', in Samuel Williamson and Peter Pastor, eds., Essays on World War I (New York: Brooklyn College Press, 1983), 69 and 74.

${ }^{13}$ Theodore Abel, 'The Elements of Decision in the Pattern of War', American Sociological Review, Vol.6, No.6 (1941), 858; Ole Holsti, 'The 1914 Case', American Political Science Review, Vol.59, No.2 (1965), 365-78; Jack Levy, 'Preferences, Constraints and Choices in July 1914' International Security, Vo.15, No.3 (Winter 1990/91), 154.
} 
France...' 14 The Earl of Beauchamp, the First Commissioner of Works - who submitted his resignation over the war, then withdrew it - insisted, 'I remained because I thought... great British interests were at stake...' while the local government minister, Herbert Samuel, feared a Cabinet split would lead to the creation of a Coalition or a Conservative administration, 'either of which would certainly have been a war ministry.' 15

The tendency for ministers to explain their behaviour in rational terms is evident across the board, despite deep differences in outlook over the crisis. The three who resigned also justified themselves in these terms: Lord Morley, Lord President of the Council, warned Asquith that, 'To swear ourselves to France is to bind ourselves to Russia', with its autocratic regime; John Burns, President of the Board of Trade, feared that, if Britain committed itself to defend the French coast from a German naval attack, Berlin could be justified in declaring war; and Charles Trevelyan, a junior education minister (outside Cabinet), complained the entente cordiale with France had been turned into an alliance, a 'policy I believe to have been wrong., 16 Significantly, references to emotions tended to made by politicians only in a negative sense, when criticising opponents. Thus, Samuel claimed those who resigned made a 'subjective rather than objective' decision, 'due less to a judgement on the merits of the case' than 'a feeling' they could not preside over a war; whereas Trevelyan condemned Grey's speech of 3 August, the government's key public statement in

\footnotetext{
${ }^{14}$ British Library, London, John Burns papers, Add. Mss. 46303, Hobhouse to Burns, 7 August; British Library, J.A. Spender papers, Add. Mss. 46386, Runciman to Spender, 4 November 1929, and McKenna to Spender, 8 May 1929.

${ }^{15}$ Bodleian Library, Oxford, John Morley papers, Ms.Eng.d.3585, Beauchamp to Morley, 6 August; Bernard Wasserstein, Herbert Samuel (Oxford: Clarendon Press, 1992), 163.

${ }^{16}$ Morley to Asquith, 4 August, in Viscount Morley, Memorandum on Resignation (London: Macmillan, 1928), 31; Wasserstein, Samuel, 162; Newcastle University Library, Walter Runciman Papers, WR135, Trevelyan to Runciman, 4 August.
} 
favour of intervention, for its 'bare-faced appeal to passion...' Yet, Grey was keen to defend himself from accusations of emotionalism: he did not intend 'to stir indignation, and the House ought to come to its decisions on grounds of weight, not of passion. ${ }^{17}$

This insistence that decisions were rationally-based, married to criticism of any signs of emotion, is unsurprising. In 1914, government ministers were all males: emotional outbursts were associated with weak, feminine behaviour. For one one Labour M.P., listening to Grey's speech, 'the atmosphere soon resembled that of a hysterical meeting of excited ladies, rather than that of a parliamentary debate on which the lives and happiness of millions depended. ${ }^{18}$ Men were supposed to demonstrate bravery, resilience and self-control, and both sides of the debate sought to act within these expectations. Samuel warned his wife, 'We nineteen men round the table at Downing St. may soon have to face the most momentous problem which men can face', while Lord Haldane, the Lord Chancellor, told his sister, 'I must put all other thoughts aside \& try to play a man's part.' ${ }^{19}$ They were not the only ones to link strength and masculinity in interpreting their own approach to the crisis. In seeking to dissuade Trevelyan from resignation, Runciman argued that three sceptics about intervention - Chancellor of the Exchequer David Lloyd George, Colonial Secretary Lewis Harcourt and education minister Jack Pease - had decided 'our duty - and each man alone can decide for himself - is to remain where we are, and with our full

\footnotetext{
${ }^{17}$ Herbert Samuel, Memoirs (London: Cresset Press, 1945), 104; Newcastle University Library, Charles Trevelyan Papers, CPT59, 'Personal record of the days that led up to the war'; Viscount Grey, Twenty-Five Years, Volume II (London: Hodder and Stoughton, 1925), 14.

${ }_{18}$ J.R. Clynes, Memoirs, 1869-1924 (London: Hutchinson, 1937), 168-9.

${ }^{19}$ Parliamentary Archives, Herbert Samuel papers, A/156/691, Herbert to Beatrice Samuel, 29 July; National Library of Scotland (NLS), Edinburgh, Richard Haldane papers, MS.5991, Haldane to his Sister, 2 August.
} 
strength devote ourselves to the terrible work... ${ }^{20}$ This is not to say that women were immune to ideals of duty or feelings of excitement over war. The practice of sending white feathers to men who failed to enlist is well known and Margot Asquith, wife of the Prime Minister, could not understand why the Attorney-General, Sir John Simon, considered resignation: "what a fool he wd. have been to have left politics at the most wonderful time in history!'21

\section{The Presence of Emotions}

No-one should really be surprised that references to emotions are found in the historical record but, as Ute Frevert points out, until recently, while historians 'all saw the power of emotions in politics, in daily life, in social movements... [u]nfortunately, they were all Cartesians - dismissing emotions... as something primitive and irrational. ${ }^{22}$ It might be expected that the claims they made to rationalism, as well as their tendency to dismiss or criticise decisions based on emotions, would have led politicians to minimise references them in their accounts, thus making it difficult for historians to uncover trace their impact. But, a trawl of memoirs, diaries and letters in fact reveals abundant evidence those at the centre of events were passionately affected by the crisis, which unfolded with astonishing speed. ${ }^{23}$ On 29 July, the day after Austria-Hungary declared war on Serbia, King George V wrote, 'please God it will not come. These are very anxious days for me to live in.' Henry Wickham Steed, foreign editor of The Times, called 1 August, the day Germany declared war on Russia, 'the most terrible day of my life.' For Maurice Hankey, a senior civil servant,

\footnotetext{
${ }^{20}$ Runciman Papers, WR 135, Runciman to Trevelyan, 4 August.

${ }^{21}$ Nicoletta Gullace, 'White Feathers and Wounded Men: female patriotism and the memory of the Great War', Journal of British Studies, Vol. 36, No. 2 (1997), 178-206; Bodleian Library, Lewis Harcourt papers, Ms. Harcourt 421, Margot Asquith to Harcourt, 14 August.

${ }^{22}$ Frevert, 'History of Emotions', 68.

${ }^{23}$ Recent accounts include: Clark, Sleepwalkers; Thomas Otte, July Crisis (Cambridge University Press, 1914); Gordon Martel, The Month that Changed the World (Oxford University Press, 2014).
} 
the following few days, culminating in Britain's declaration of war on 4 August, 'blurred in my recollection except that the pressure of work was continuous, and that my sleep (at the office) was much disturbed... ${ }^{24}$

It could be no different for Cabinet ministers, especially, as Augustine Birrell, Chief Secretary for Ireland, said, 'No occurrence can ever be so disheartening... to a Liberal Government... as the outbreak of an European war...' There was also the fact that the war crisis overlapped with fears of civil war in Ireland, where trouble had been brewing for months. Already, on 27 July, Haldane told his mother, 'This is the most trying time, I think, we have had since the Ministry was formed.' Futhermore, by 31 July, rumours of war had triggered a financial crisis and Harcourt recorded Lloyd George's report to Cabinet in almost apocalyptic terms:

Gov[ernor] of Bank of England \& all City opinion aghast at any possibility of our being dragged in. Business men in North say if we were, all mills, factorys [sic], mines, shipping etc. stopped... One man s[ai]d to him... "England will be in revolution in a week."

The next day, meetings were continuous: the morning Cabinet ended at 1 p.m., but Harcourt and several other ministers then met to discuss finance and did not expect to break up until midnight; another Cabinet was fixed for 11 a.m. the following morning. ${ }^{25}$

\footnotetext{
${ }^{24}$ The King quoted in Catrine Clay, King, Kaiser, Tsar: three royal cousins who led the world to war (London: John Murray, 2006), 307; Henry Wickham Steed, Through Thirty Years, 1892-1922, Volume II (London: Heinemann, 1924), 10; Lord Hankey, The Supreme Command, 1914-18, Volume I (London: George Allen and Unwin, 1961), 161.

${ }^{25}$ Augustine Birrell, Things Past Redress (London: Faber, 1937), 224; Haldane papers, MS.5991, Haldane to his Mother, 27 July; Harcourt papers, Ms.Eng.c.8269, Political Journal [hereafter Harcourt Journal], 31 July, and Ms.Eng.d.4192, Lewis to Mary Ethel Harcourt, 1 August.
} 
The cumulative effect of a multifaceted crisis and days of meetings inevitably had a draining effect, which heightened emotions and was, in fact, readily acknowledged by ministers. In his memoirs, in a remark little-noticed by historians, Grey acknowledged, 'so much working of the mind is subconscious rather than conscious' and that one element in decision-making in 1914 was its 'immense strain.' On 4 August, as diplomatic crisis gave way to war, Runciman wrote of having gone through 'ten days of anxiety and torturing thought...' Similarly, Winston Churchill, First Lord of the Admiralty, remembered these as days of 'stress and convulsion. 26 Such emotions also had a physical effect. Harcourt's Private Secretary noted, 'I will never forget his appearance at 6 o'clock on the evening of 4 August. He was absolutely worn out, and looked like death.' Haldane's sister recorded him and Grey as suffering sleeplessness and indigestion in the face of 'immense strain. ${ }^{27}$ The stressful atmosphere also made it hard to keep a balanced view: Beauchamp admitted, 'It is very difficult to sit down calmly in the middle of a crisis to record events as they fly by.' Aside from being busy and tired, ministers were tormented by the prospect war might somehow be avoided, as reflected in Haldane's remark, 'I shall not give up hope till war breaks out. I trust we shall not be dragged in. It is fearfully difficult to steer. $^{28}$

\section{Emotional Biography}

If it is accepted that ministers were under great emotional strain, what evidence is there that this may have impacted on British decision-making? International historians

\footnotetext{
${ }^{26}$ Grey, Twenty-Five Years, II, 1 and 10; Runciman Papers, WR135, Runciman to Trevelyan, 4 August; Winston Churchill, The World Crisis, Volume I (London: Odhams, 1938), 184.

${ }^{27}$ R.R. James, Memoirs of a Conservative: J.C.C. Davidson's papers, 1910-37 (London: Weidenfeld and Nicolson, 1969), 20; NLS, Elizabeth Haldane papers, Ms. 20240, diary, 8 August.

${ }^{28}$ Peter Raina, The Seventh Earl of Beauchamp (Oxford: Peter Lang, 2016), 310; Haldane papers, MS.5991, Haldane to his Mother, 1 August.
} 
have generally shown little interest in the linguistic and cultural 'turns' and, as Laura McEnaney says, are still 'quite focused on decisive moments and pivotal people. ${ }^{29}$ But these 'pivotal people' were undoubtedly affected by emotions in taking decisions. Several scholars involved in the broader 'emotional turn' have stressed the importance of biography to the study of emotions. From an anthropological perspective, Andrew Beatty contends that, while emotions 'might be third-person constructions, a collective product, they are first-person experiences... Their particularity is to do with their subjectivity...' Michael Roper has warned gender historians against an approach in which the "varied emotional experiences that constitute the domain of subjectivity are flattened into a version of collective consciousness... ${ }^{30}$ The psychologist Carroll Izard has proposed that emotions should be divided into two types: 'basic emotions' (most obviously, the response to suddenly encountering a snake, when the emotion of fear may well decide the reaction, with reason having no time to be engaged); and 'emotion schemas'(when emotions have time to 'interact dynamically with perceptual and cognitive processes...', which would be more usual during a crisis that stretched over several days, as in July 1914). Izard, too, then emphasises the link between emotions and biography, arguing that motion schemas are 'influenced by individual differences, learning, and social and cultural contexts' and may lead to 'emotion traits' in individuals. ${ }^{31}$ International historians may be attracted to an approach that not only allows them to maintain an emphasis on particular actors, but also encourages them to deepen their understanding of these individuals by exploring their emotional make-up.

\footnotetext{
${ }^{29}$ Laura McEnaney, 'Personal, Political and International: a reflection on diplomacy and methodology', Diplomatic History Vol. 36, No. 4 (2012), 772.

${ }^{30}$ For example: Andrew Beatty, ‘Anthropology and Emotion' Journal of the Royal Anthropological Institute, Vol. 20, No. 3 (2014), 551; Michael Roper, 'Slipping out of View: subjectivity and emotion in gender history', History Workshop Journal, Issue 59 (2005), 59.

${ }^{31}$ Izard, 'Emotion Theory', 8-9.
} 
The first point to make here is that, in such a charged situation, respect went to those individuals who retained their self-control, not least Asquith. Several ministers commented on the calm that he demonstrated, even at the most trying points. When, on 1 August, Churchill asked him to approve naval mobilisation in the face of Cabinet doubts, 'The Prime Minister simply... looked at me and said no word... [I] sustained the impression that he would not put out a finger to stop me.' Before the next Cabinet, Lloyd George and Harcourt warned Asquith they 'represented 8-10 colleagues who w[oul]d not go to war for Belgium', but he simply 'listened, s[ai]d nothing.' Over lunch at Downing Street on 2 August, following the most difficult Cabinet of the crisis, Pease felt 'there was a forced effort at cheerfulness', but the Prime Minister was 'most natural... we discussed word derivation \& the soundness of Dryden's English... ${ }^{32}$ It is clear from other ministers' comments that such sangfroid won Asquith respect. The same day, Edwin Montagu, a junior Treasury minister, wrote, 'Panic follows panic... hopes vanish and revive only to be dashed again - nothing but blackness ahead... the marvellous calmness of the PM is our only national asset', while Charles Masterman, Chancellor of the Duchy of Lancaster, felt Asquith 'acted with great dexterity and good temper' throughout the crisis. ${ }^{33}$ This may help to explain why most ministers remained loyal to the Prime Minister and shrank from resignation, a point that will be discussed further below.

\footnotetext{
${ }^{32}$ Parliamentary Archives, Lord Beaverbrook papers, BBK/C/86, Churchill to Beaverbrook, 18 March 1928; Harcourt Journal, 2 August; K.M. Wilson, ed., 'The Cabinet Diary of J.A. Pease, 24 July-5 August 1914', Leeds Philosophical and Literary Society, Vol. XIX, No. 3 (1983) [hereafter Pease diary], 9.

${ }^{33}$ Trinity College, Cambridge, Edwin Montagu papers, II C 1/118, Montagu to Mother, 2 August; Lord Riddell, War Diary (London: Ivor Nicholson, 1933), 6.
} 
The other main figure at the epicentre of debate was Grey. Later accused by Lloyd George of 'a temperamental failure' in 1914, he won plaudits at the time from his colleagues (including the Chancellor) for calmness and responsibility. ${ }^{34}$ Haldane recorded on 29 July that Grey was 'marvellously cool and concentrated', while Samuel remarked, 'It is marvellous how serene, and indeed cheerful, he keeps.' Even John Burns, President of the Board of Trade, who felt war 'a universal crime' and resigned over it, commented on 1 August, 'Grey wears well under the sustained pressure. ${ }^{35}$ Edmund Gosse, the literary critic, saw Grey on 2 August, finding him 'perfectly calm, but grave to solemnity...' As if to exhibit his self-control, the Foreign Secretary 'took the motor, and went off to the Zoo, to spend an hour among the birds. ${ }^{36}$ Having negotiated the difficult Cabinets of the 2nd, Grey faced the House of Commons on the 3rd. His Parliamentary Private Secretary, Arthur Murray, considered, 'It was the supreme moment of his life and he rose to it magnificently.' The speech served to ease the emotions of Grey's fellow-interventionists. While Trevelyan, as seen above, condemned the speech's 'bare-faced... passion', Hobhouse believed its 'sincerity, exhibiting the depth of feeling of the speaker, contributed greatly to the effect it had on its audience. ${ }^{37}$ There is evidence that Grey was less steady than he appeared. When American Ambassador Walter Page saw him on 28 July, 'he looked 10 years older than he looked a month ago'38 and Runciman later judged that, although Asquith 'never lost the regularity of his stride', Grey 'nearly

\footnotetext{
${ }^{34}$ David Lloyd George, War Memoirs, Volume I (London: Odhams, 1938), 58-60; Trevor Wilson, ed., The Political Diaries of C.P. Scott, 1911-28 (London: Collins, 1970), 99.

${ }^{35}$ Haldane papers, MS.5991, Haldane to his Mother, 29 July; Richard Haldane, An Autobiography (London: Hodder and Stoughton, 1929), 273; Samuel papers, A/156/692, Herbert to Beatrice Samuel, 30 July; Burns papers, Add. Mss. 46336, diary, 27 July and 1 August.

${ }^{36}$ Evan Charteris, The Life and Letters of Sir Edmund Gosse (London: Heinemann, 1931), pp. 366-68.

${ }^{37}$ National Library of Scotland, Murray of Elibank papers, MS.8814, diary, 3 August; David, ed. Asquith's Cabinet, 180.

${ }^{38}$ Arthur Link, ed., The Papers of Woodrow Wilson, Volume 30, May-September 1914 (Princeton University Press, 1979), 314-16.
} 
broke under the strain... ${ }^{39}$ Grey's memoirs suggest, however, that his nerves only gave way with the coming of war: 'responsibility elevates when it does not crush. But when... the hope of peace was gone, the strain was felt more severely., 40

Whilst an image of stability could only help Asquith and Grey command respect during the crisis, it is also evident that signs of emotional instability drew criticism. Harcourt was especially critical of Lloyd George and Churchill for volatility. In Cabinet on 27 July he had found both belligerent. Two days later, however, Lloyd George seemed to be 'in full flight to us (Peace party) ... Winston also less bellicose, also wants to be on popular side... but these popularity hunters not to be trusted.' Runciman, too, found the Chancellor 'vacillating... Right up to teatime on Sunday, August 2, he told us that he was doubtful of the action he would take. ${ }^{41}$ Lloyd George provoked less concern than Churchill, however. By 30 July, Harcourt feared he 'has gone mad' and the following day felt 'Winston very angry overwrought \& excitable.' Pease, too, judged Churchill to be 'bellicose and aggressive. ${ }^{42}$ Following the morning Cabinet of 2 August, the Prime Minister's daughter, Violet, found 'Winston alone was buoyant...' and Masterman accused Churchill of exhibiting 'light-hearted irresponsibility' in discussing war. ${ }^{43}$ Churchill was troubled by his own excitement, telling his wife, 'Everything tends towards catastrophe and collapse. I am interested, geared up and happy. Is it not horrible to be built like that?' Yet, however disturbing his enthusiasm, his very emotional

\footnotetext{
${ }^{39}$ Runciman Papers, WR136/18, Runciman to Chalmers, 17 February 1915.

${ }^{40}$ Grey, Twenty-Five Years, II, 12.

${ }^{41}$ Harcourt Journal, 29 July; Arthur Murray, Master and Brother (London: John Murray, 1945), 120

${ }^{42}$ Harcourt Journal, 30 and 31 July; Pease Diary, 7.

${ }^{43}$ Violet Bonham-Carter, Winston Churchill as I Knew Him (London: Collins, 1965), 309; Wilson, ed., Political Diaries, 99.
} 
preparedness for war helped him ensure the Navy was mobilised as Britain entered the conflict. ${ }^{44}$

\section{Resignations}

The emotional biography of individuals seems to have had a significant impact on whether Cabinet ministers, who initially undertook to resign over war, actually went through with this threat. The two who did resign - Burns and Morley - were clearly at ease with their eventual decision, as was Trevelyan, the one non-Cabinet minister to go. True, Hobhouse's diary suggests that Burns, who had long been suspicious of British ties to France, was in considerable turmoil before becoming the first to depart, on 2 August:

'Burns was saying on Sunday morning that this meant either unconditional neutrality or (leaning over the table, shaking his clenched fists) war with both hands... At the end of our meeting J.B. leant forward and in a few words of deep feelings said he must separate himself from his colleagues... and from a P.M. whom he loved. He was moved to tears. ${ }^{45}$

Similar to Churchill's case, emotionalism and determination seemed to unite in Burns. Morley was evidently less agitated and outspoken, so that colleagues at first disbelieved his threat to go. 'As he had said the same thing about once a month for 3 years,' commented Hobhouse, 'no-one took this very seriously. ${ }^{46}$ Morley was more torn than Burns perhaps, admitting that resignation was difficult: 'It concerns a man's principle and creed; it affects confidential relations with fellow-workers; it concerns his party...' When Asquith pleaded for him to stay by playing on his emotions - 'to

\footnotetext{
${ }^{44}$ Randolph Churchill, ed., Winston Churchill: Companion Volume II, Part 3, 1911-14 (London: Heinemann, 1969), 1989-90.

${ }^{45}$ Edward David, ed., Inside Asquith's Cabinet: from the diaries of Charles Hobhouse (London: John Murray, 1977), 179-80.

${ }^{46}$ David, ed., Asquith's Cabinet, 179-80.
} 
lose you in the stress of a great crisis is a calamity which I shudder to contemplate' Morley felt 'mental anguish held me by the throat.' But ultimately, his 'nerve had become as good as usual, my temper as cool' as he confirmed his wish to go. ${ }^{47}$ The calmest of the trio who departed was Trevelyan, who became distrustful of Grey during a meeting in late July. When Trevelyan remarked that there was no reason for Britain to become involved in the crisis, Grey, 'replied in an extraordinarily hard, unsympathetic way. He seemed to be coldly angry with me.' This 'created a profound distrust' in Trevelyan's mind. By 2 August, he 'began to feel rage, and to say that I would work at any cost for peace.' On resigning, he told his wife, 'It was singularly easy to do, as I saw so clearly that I had got to do it. ${ }^{48}$

Among the Cabinet ministers who decided to remain in office, some claimed a similar ease over their decision. Birrell later recalled, 'When the fateful decision had to be made I was not troubled with any doubt as the course to be taken', and Samuel claimed he 'spent no sleepless nights weighing up the pros and cons. ${ }^{49}$ But other minister's nerves failed, the starkest example being Simon who, like Beauchamp, submitted his resignation, then withdrew it. Morley later claimed to have been 'specially concerned about Simon's position. In the Cabinet he was labouring under great emotion \& tears were in his eyes. ${ }^{50}$ By 4 August, Simon was 'looking terribly warn and tired' and impressed one observer with 'his utter prostration. Morally and physically he was like a man half dead...' Having withdrawn his resignation, he claimed in one conversation that going would have been 'the easiest course' and that 'by staying... he might do some little good'; while in another, as if searching for

\footnotetext{
${ }^{47}$ Morley, Memorandum, 15-17 and 29-31.

48 Trevelyan Papers, CPT59, 'Personal Record' and CPT EX106, Charles to Molly Trevelyan, 27 and 29 July, 4 August.

${ }^{49}$ Birrell, Things Past, 234; Samuel, Memoirs, 102.

50 The National Archives, Kew, MacDonald Papers, PRO30/69/1753/1, diary, 6 October.
} 
excuses, he argued that, if several ministers had resigned, it 'would necessitate a Coalition Government which would assuredly be the grave of Liberalism. ${ }^{51}$ His change of mind drew contempt from at least one colleague: Hobhouse felt Simon's behaviour 'almost despicable because he pretended to a special and personal abhorrence of killing in any shape. ${ }^{52}$ But the many references to Simon's state of mind suggest that the intense stress of the situation prevented him from taking a consistent, rational course.

\section{Honour}

One pressure on Simon was Asquith's insistence that there was what 'approaches to a public duty' to stay in office. ${ }^{53}$ It has already been claimed that, 'Grey and Asquith manipulated the situation deftly, using emotional appeals to British honour... to convert the Cabinet' to intervention. ${ }^{54}$ Honour, closely associated with emotional appeals to duty, loyalty and courage, alongside a condemnation of behaviour that smacked of cowardice or betrayal, was a significant element in the male-dominated political world of 1914 - and not just in Britain. The phenomenon has already received scholarly attention. Avner Offer has argued that the July Crisis was 'a chain of insults that no leader in a position of public visibility could afford to ignore' and that honour codes, viewed by their holders as a tangible possession, helped create a situation in which 'inhibitions against war were dangerously low.' Ute Frevert has emphasised how 'honor, dishonour and shame... served as powerful... frames of reference' in 1914, allowing leaders to pose as defenders of their country's international reputation. (Frevert also argues that, over the past century, such

\footnotetext{
${ }^{51}$ Wilson, ed., Political Diaries, 96-8; Christopher Addison, Four and a Half Years: a personal diary (London: Hutchinson, 1954), 35.

52 David, ed. Asquith's Cabinet, 180.

${ }^{53}$ Raina, Beauchamp, 311.

${ }^{54}$ David Silbey, The British Working Class and Enthusiasm for War (London: Routledge, 2005), 18.
} 
emotions associated with honour codes have declined in importance, while compassion and empathy have become more prominent.) The significance of honour for British policy-makers during the July Crisis is underlined by Zachary Twamley, who shows it was held in 'genuine and sincere reverence' by both interventionists and anti-interventionists. ${ }^{55}$

In Britain, honour was bound up with a belief, probably born of being a trading nation, that individuals should fulfil their contractual obligations and here, too, a link may be seen between emotion and rational thinking: it made commercial deals more certain when merchants knew that agreements would be fulfilled; but the fulfilment of contracts - or of international treaties where foreign policy was concerned - was then underpinned by emotions associated with adhering to one's word. For Cabinet ministers, ideas of honour were especially significant in the debate over British treaty commitments to Belgium, the subject of an 1839 guarantee of neutrality by the great powers, as well as to France and Russia, with whom ententes had been struck in 1904 and 1907 respectively. On 2 August, with Britain's decision in the balance, French Ambassador Paul Cambon complained 'I do not even know whether this evening the word "honour" will not have to be struck out of the British vocabulary. ${ }^{56}$ The same day, opposition leaders wrote to Asquith saying, 'it would be fatal to the honour and security of the United Kingdom to hesitate in supporting France and Russia at the present juncture.' Even professional diplomats were privately critical of the Cabinet. Eyre Crowe, Assistant Under-Secretary at the

\footnotetext{
${ }^{55}$ Avner Offer, 'Going to War in 1914: a matter of honor?', Politics and Society, Vol. 23, No. 2 (1995), 234-35 and 228; Ute Frevert, 'Honor, Gender and Power', in Holger Afflerbach and David Stevenson, eds, An Improbable War? The outbreak of World War One and European political culture (New York: Berghahn Books, 2007), chapter 13; Frevert, Emotions in History - lost and found (Budapest: Central European University Press, 2011); Zachary Twamley, A Matter of Honour: Britain in the First World War (Point Pleasant, NJ: Winged Hussar Publishing, 2016), 74-5.

${ }^{56}$ Steed, Thirty Years, II, 14.
} 
Foreign Office, told his wife, on 1 August, that the Cabinet had 'finally decided to run away, and to desert France in her hour of need.' At the Foreign Office, he claimed, 'practically everyone wants to resign rather than see a government of dishonourable cowards' and he apparently dissuaded five officials from resigning. Yet, Crowe himself believed that, 'to desert one's post at this hour would be worse dishonour., 57

During the Cabinet meetings of 2 August, Morley discovered, 'An entente is vague, rests on points of honour... here we were confronted by engagements that were vast indeed, because indefinite and undefinable... ${ }^{58}$ Nonetheless, while ministers were prepared to protect France from a German naval attack, they were unwilling to give a more general promise to fight and it was Belgium that became the focus of debate the following day, a significant point being Lloyd George's announcement that 'the invasion of a neutral state made all the difference to him...,59 Churchill was one of those happy to exploit Belgium as justification for war: 'if we allowed Belgian neutrality to be trampled down by Germany... we shd be in a very melancholy position both in regard to our interests and our honour. ${ }^{60}$ Pease, a Quaker, justified his eventual support for war partly through a desire to protect Belgium: 'to repudiate our undertaking to preserve Belgium's neutrality would be dishonourable... it would be a cowardly and selfish act on my part to seek my own rest of mind and leave to my colleagues the distasteful and hateful work. ${ }^{61} \mathrm{He}$ was not the only anti-interventionist to defend remaining in office as some kind of

\footnotetext{
${ }^{57}$ Parliamentary Archives, Lloyd George papers, LG/C/6/11/20, Law to Asquith, 2 August; Bodleian Library, Eyre Crowe papers, Ms.Eng.e.3020, Eyre to Clema Crowe, 1 August.

${ }^{58}$ Morley, Memorandum, 17-18.

${ }^{59}$ Pease diary.

${ }^{60}$ Churchill, ed., Companion, II, Part 3, 1995-96.

${ }^{61}$ Trevelyan Papers, CPT59, Pease to Hodgkin, 4 August.
} 
emotional sacrifice: Lloyd George complained, 'I must bear my share of the ghastly burden though it scorches my flesh to do so. ${ }^{62}$

There were some ways of resisting appeals to honour. In a letter to his constituents, Trevelyan declared, 'Grey's appeal to "honour” leaves many of us untouched', because 'it carried with it the duty of enmity to Germany', while Harcourt, after deciding to remain in government, insisted, 'I have acted not from any obligation of Treaty or of honour, for neither existed... ${ }^{63}$ An alternative strategy was to dismiss honour as an outmoded concept. Trevelyan called it 'that hateful medieval survival' and Dolly Ponsonby, wife of an anti-war M.P., as a 'lifeless and academic code. ${ }^{64}$ Other anti-interventionists - unable perhaps to escape from the cultural belief-system that surrounded them - accepted that honour existed, but claimed it did not commit Britain to war. Thus, Burns wrote that, 'Honour, Duty, Humanity all unite in my protest against this wanton war' and Ramsay MacDonald, the Labour leader, declared, 'this country ought to have remained neutral, because... that alone was consistent with the honour of the country... ${ }^{65}$ Yet, whatever doubts some expressed, appeals to honour now became a key factor in motivating parliament and the country to fight, as did associated appeals to loyalty and duty.

\section{Loyalty}

It is possible, from the record, to distinguish the role played by appeals to loyalty, unity and duty in minimising ministerial resignations, linked to feelings of despair

\footnotetext{
${ }^{62}$ Kenneth Morgan, ed., Lloyd George Family Letters (Cardiff: University of Wales Press, 1973), 167.

${ }^{63}$ Manchester Guardian, 7 August; Hazlehurst, Politicians, 114.

${ }^{64}$ Trevelyan Papers, CPT EX106, Charles to Molly Trevelyan, 30 July ; Duncan Marlor, Fatal Fortnight (London: Frontline, 2014), 145.

${ }^{65}$ Burns papers, Add.Mss. 46282, 'Note to a Friend', 3 August; House of Commons Debates, Vol. 65, column 1831.
} 
over being separated from former colleagues. Beauchamp recalled that, late in the 2 August Cabinets, after said he would resign, 'Everybody formed in a chorus of dissension \& the PM spoke forcibly on deserting colleagues, etc.' Asquith used similar tactics against potential resignations the following morning:

The P.M., whose eyes filled with tears, said... they were men for whom he had regard and friendship; the party was still hesitating; the country was in danger and unity of counsel was essential. ${ }^{66}$

Simon nonetheless submitted a letter of resignation, while conceding that, if the country was at war, 'it was the duty of men like himself and the peace party to support the Govt.' It has already been seen that he later withdrew his resignation, after Asquith insisted he had a public duty to remain. Asquith's ability, not only to remain calm, but also to manipulate the emotions of others, is underlined by his generous letter to Simon as the latter agonised over the situation:

'Whatever decision you come to, I shall always most gratefully and affectionately recognise and remember your invaluable service to the Government... ${ }^{, 67}$

Appeals from the Prime Minister evidently carried special weight, because of the personal loyalty he commanded. Beauchamp told Asquith, on 3 August, that he delayed resignation because of 'a real anxiety to cooperate as long as possible with colleagues $\&$ a chief for whom I have a great admiration $\&$ respect.' Burns believed that Beauchamp 'felt as we did but was only persuaded to stay against his better judgment by PM' and Beauchamp admitted to Morley that it felt 'presumptuous to set

\footnotetext{
${ }^{66}$ Raina, Beauchamp, 310; David, ed. Asquith's Cabinet, 180.

${ }^{67}$ Raina, Beauchamp, 311.
} 
up my own opinion against that of one to whom I owe so much allegiance as to the Prime Minister. ${ }^{68}$ The Prime Minister was aided by other ministers, including Lloyd George, who made 'a strong appeal to them not to go...' on 3 August. The power of appeals to loyalty and the pain of separation are reflected in Morley's admission that, while he went through with resignation, 'personal attachments have made the last few days truly lacerating. ${ }^{69}$ Trevelyan, too, was put under considerable pressure to remain in office. Runciman tried to dissuade him from going by depicting those who remained as the courageous ones: 'we decided against at present taking the easy course of washing our hands of the dreadful responsibilities...' When Trevelyan persisted, Pease stepped in: 'I would urge you to recall your resignation \& pluckily face with our great Prime Minister the responsibilities forced on the Government.' The Chief Whip, Percy Illingworth, similarly declared, 'At a moment when we are fighting for our national existence, this is not the moment to weaken the government by resignation. ${ }^{70}$ The appeals failed in Trevelyan's case, but Asquith - pleased with the 'slump in resignations' on 4 August - could now be contemptuous about 'Master C. Trevelyan... Happily, il n'y a pas d'homme nécessaire. ${ }^{71}$ It is a contempt that suggests that Asquith's earlier generosity to the potential departees had been a calculated move.

The Prime Minister's success was probably also aided by the intense passions in Cabinet that arose once it was clear that old friendships might be broken - passions that undermine the stereotype of the British 'stiff upper lip.' Until 2 August,

\footnotetext{
${ }^{68}$ Raina, Beauchamp, 310-11; Burns papers, Add.Mss. 46337, diary, 5 August 1915; Morley papers, Ms.Eng.d.3585, Beauchamp to Morley, 4 and 6 August.

${ }^{69}$ Brock, eds., Letters, 148; Alfred Havighurst, Radical Journalist: H.W. Massingham (Cambridge University Press, 1974), 229.

${ }^{70}$ Runciman Papers, WR 135, Runciman to Trevelyan, 4 August; Trevelyan Papers, CPT59, Pease to Trevelyan, 5 August, and Illingworth to Trevelyan, 4 August.

${ }^{71}$ Brock, eds., Letters, 150.
} 
emotional outbursts were few. Asquith even felt the previous day's Cabinet 'parted in a fairly amicable mood. ${ }^{72}$ But, there then followed a general breakdown of male stoicism, which included diplomats as well as ministers. On 2 August, Grey told the Cabinet that Ambassador Cambon, who had toiled for a decade to build up the entente cordiale, 'had twice wept over our statement that we were not committed.' Similarly, Asquith reported that, when he met the anglophile German Ambassador, Prince Lichnowsky, the latter 'was very agitated poor man \& wept' at the thought of their two countries going to war. ${ }^{73}$ The most dramatic accounts of emotional release, however, come from within the Cabinet as serious talked of resignations mounted. Harcourt's journal records that, on 2 August, Burns was 'almost in tears' as he announced his departure and Lloyd George recalled that Grey 'burst into tears - an extraordinary and moving thing in a man so reserved. ${ }^{, 74}$ Even more charged was the morning session of 3 August, when Asquith reported Burns, Morley and Simon from were going and Beauchamp then said he too must leave. As Pease's account describes the scene:

'[T]hat is 4 said the P.M. out of our number... God knows I should like to be relieved of all this, then he alluded to personal attachment $\&$ his indebtedness to Morley and broke down... Simon broke down in saying he would do his utmost outside to secure unity... Grey said he felt some responsibility for the resignations \& felt it acutely \& broke down. ${ }^{, 75}$

As Samuel summed it up: 'The Cabinet was very moving. Most of us could hardly speak at all for emotion. ${ }^{97}$

\footnotetext{
${ }^{72}$ Brock, eds., Letters, 140.

${ }^{73}$ Pease diary, 8-9; Brock, eds., Letters, 146.

${ }^{74}$ Wilson, ed., Political Diaries, 99.

${ }^{75}$ Harcourt Journal, 2 August; Pease Diary, 10.

${ }^{76}$ Wasserstein, Samuel, 164.
} 
Even after the resignations were resolved, Asquith was aided by the reluctance of Burns and Morley to criticise those who remained. Burns directed his emotions towards grief rather than anger, claiming 'The sadness, badness and madness of it all fills me with a merciful condolence rather than a blazing wrath, but the wrath will come. ${ }^{, 77}$ Morley showed no bitterness to Beauchamp, who withdrew his resignation: 'The pressure for remaining was, I felt myself, so intense, and I have no word of reproach for those who hold on.' (Only later did Morley complain that Harcourt 'ran away at the last moment.' $)^{78}$ The departing pair may also have found it difficult to speak because of the despair expressed by former colleagues, to whom they still felt a bond. Hobhouse told Burns, 'I feel your withdrawal a personal loss', while Grey wrote, 'I can't tell you how much I grieve to see your vacant place. ${ }^{79}$ In similar terms, he told Morley: 'My heart is too full of all the misery of this time to let me write what I feel. I am choked with it.' With war declared, it was even possible to grant that the resignees had behaved well. In expressing his 'sincere grief at our official... parting' to Morley, Crewe added, 'I'm not going into our reasons, or into what I conceive to be yours: we know that they are all honourable.' Even the bellicose Churchill, having got the conflict he craved, could write that there was 'no reason for anyone to be ashamed of honest and sincere counsel given either to preserve peace or to enter upon... war. ${ }^{80}$

\section{The Bethmann-Hollweg Letter}

A focus on emotions can help to explain why ministers decided to declare war over Belgium on 4 August, despite having decided, at an earlier discussion on 29 July, that

\footnotetext{
${ }^{77}$ Burns papers, Add.Mss.46282, Burns to Margot Asquith, 15 August.

${ }^{78}$ Newton, Darkest Days, 254; MacDonald Papers, PRO30/69/1753/1, diary, 6 October.

${ }^{79}$ Burns papers, Add.Mss.46303, Grey to Burns, 5 August, and Hobhouse to Burns, 7 August.

${ }^{80}$ Morley papers, Ms.Eng.d.3585, Grey to Morley, 10 August, and Crewe to Morley, 7 August; Churchill, World Crisis, 1, 160.
} 
the issue was "rather one of policy than of legal obligation. ${ }^{91}$ One way to explain this apparent inconsistency, is to adopt Morley's argument that, 'The precipitate and peremptory blaze about Belgium was due less to indignation at the violation of a Treaty than to natural perception of the plea that it would furnish for intervention on behalf of France. ${ }^{82}$ Morley’s argument has been echoed in some later analyses. ${ }^{83}$ But the importance of the guarantee has recently been reasserted ${ }^{84}$ and a focus on emotions allows a new - and very different - interpretation of the apparent inconsistency. One great difference between the situation on 29 July and 4 August lies in rising anger about German actions. In late July, anger tended to focus on AustriaHungary, over its war with Serbia: Grey's accusation of 'brutal recklessness', made at the opening of the 29 July Cabinet, was echoed by Samuel telling his mother, 'It is the wicked recklessness of Austria that is bringing about this most terrible catastrophe ${ }^{, 85}$ Harcourt's journal suggests that the initial discussion about Belgium, before Germany went to war, was dry, legalistic and distinctly unemotional: 'We discussed our liabilities for the guarantee of Belgian neutrality \& independence which rests on the European treaty of 1839. Is it a joint or several guarantee? Are we bound to observe it if other parties do not? ${ }^{86}$ Only when Germany actually menaced Belgium and other neighbours, did emotions fully come into play against it, with Austria falling into the background. In his memoirs, Grey recalled being 'stirred with resentment and indignation at what seemed to me Germany's crime in precipitating the war...' This was no retrospective invention: Samuel met Grey just before a Cabinet meeting and

\footnotetext{
${ }^{81}$ J.A. Spender and Cyril Asquith, Life of Herbert Henry Asquith, Lord Oxford and Asquith: volume II (London: Hutchinson, 1932), 81.

${ }^{82}$ Morley, Memorandum, 14.

${ }^{83}$ Most recently, Douglas Newton, The Darkest Days: the truth behind Britain's rush to war in 1914 (London: Verso, 2014), 290-93.

${ }^{84}$ Isabel Hull, A Scrap of Paper: making and breaking international law during the Great War (New York: Cornell University Press, 2014), chapter 2.

${ }^{85}$ Pease diary, 5; John Bowle, Viscount Samuel (London: Gollancz, 1957), 118.

${ }^{86}$ Harcourt Journal, 29 July.
} 
could 'never forget the passion in his voice as he [said], "There's some devilry going on in Berlin.", 87

On 1 August, Morley admitted to Sir Almeric Fitzroy, the Clerk of the Privy Council, that 'the high-handed action of Germany was weakening the efforts of the peacemakers in the Cabinet...'A number of actions help account for the growing rage over German behaviour. Over lunch with Fitzroy, for example, Beauchamp, though opposed to going to war, condemned Germany's sudden detention of some British ships as a 'provocative interference. ${ }^{88}$ When Arthur Ponsonby, chair of the antiinterventionist Liberal Foreign Affairs Group saw Harcourt, on 2 August, he reported that many MPs were upset by the invasion of Luxemburg which, like Belgium, was a neutral country (though not one Britain was treaty-bound to defend) through which the German army intended to advance against France. ${ }^{89}$

The most provocative German step, however, was a proposal from its Chancellor, Theobald von Bethmann-Hollweg, on 29 July that, if Britain remained neutral, Berlin would not annex French territory in Europe and would restore Belgian territorial integrity after the war. Grey was said by his Private Secretary, Sir William Tyrrell, to be in a 'white heat of passion' about this. ${ }^{90}$ As Sir Eyre Crowe, Assistant Under-Secretary at the Foreign Office, said, there were good rational reasons for concern over this proposal, in that it 'practically admits the intention to violate Belgian neutrality.' But, it also immediately generated a strong emotional response. Grey believed the offer 'dishonouring to Britain' and had 'a feeling of despair' on

\footnotetext{
${ }^{87}$ Grey, Twenty-Five Years, II, 14; Samuel, Memoirs, 97.

${ }^{88}$ Sir Almeric Fitzroy, Memoirs, Vol. II (London: Hutchinson, 1925), 559.

${ }^{89}$ Harcourt Journal, 2 August; Fitzroy, Memoirs, II, 559-60.

${ }^{90}$ Cameron Hazlehurst, Politicians at War, July 1914 to May 1915 (London: Jonathan Cape, 1971), 81, footnote 2 .
} 
reading it. ${ }^{91}$ Rumour of 'the astonishing German proposal' spread to M.P.s quickly and its impact was still evident on 6 August, when Asquith, moving the Vote of Credit for war, declared that the attempt 'to buy our neutrality' meant Britain would have 'bartered away our obligation to keep our plighted word', signifying 'the betrayal of our friends and the dishonour of our obligations'. Reading the speech - the Prime Minister's principal public justification of war - one might almost consider Bethmann's offer the main reason Britain had for its action, serving as it did to justify Asquith's claim that Britain fought for two principles, 'that small nationalities are not to be crushed... by the arbitrary will of a strong... Power' and 'to fulfil a solemn international obligation... which, if it had been entered into between private persons... would have been regarded as an obligation not only of law, but of honour, which no self-respecting man could possibly have repudiated.' 92

True, Bethmann's offer did not immediately convert the majority to intervention. When, in Cabinet on 31 July, Asquith talked of the 'ingenuous part Bethmann-Hollweg had played', Pease 'urged... we should do nothing provocative.' But, the Solicitor-General, Sir Stanley Buckmaster, believed that the German offer helped ensure that Harcourt, Pease and Simon would 'stick to the ship. ${ }^{93}$ There is certainly evidence in Harcourt's case that Bethmann's offer aroused a passionate response, perhaps paving the way for his change of view over the following days. On 26 July, Harcourt had told Asquith, 'under no circ[umstance]s. could I be a party to our participation in a European War.' But, when initial rumours of the German offer were heard, he told the Cabinet, 'it was inconceivable... that we should base our

\footnotetext{
${ }^{91}$ British Documents on the Origins of the War, 1898-1914, Volume XI (London: HMSO, 1926), doc. 293; Grey, Twenty-Five Years, 1, 326-27.

92 Addison, Years, 31; House of Commons Debates, Vol. 65, columns 2074-79.

${ }^{93}$ Pease Diary, 7; Addison, Years, 35.
} 
abstention on such a bargain.' Then, on 30 July, after Bethmann's proposal was officially received, Harcourt described it as 'shameful' and was happy that 'Grey... without hesitation rejected offer with (I think) some contumely. ${ }^{94}$ In this Harcourt, hitherto the leading anti-interventionist was, ironically, at one with the prointerventionist Crowe, who considered the German offer 'most cynical and dishonourable. ${ }^{95}$ Although his Private Secretary, J.C.C. Davidson, believed the Colonial Secretary was 'passionately opposed' to war until the last moment, Harcourt's diary shows that, by 2 August, he thought 'the prevention of a German fleet attack \& capture of French territory on shore of Channel a British interest' and also agreed with other ministers, 'to regard any permanent danger or threat to Belg. independence (such as occupation) as a vital Brit. interest. ${ }^{96}$

That the government's reaction to the Bethmann-Hollweg proposal was an emotional, more than a rational one, is highlighted by the comments made by Grey in his memoirs, where he was keen to defend the argument in great speech of 3 August as being based upon 'calm proofs of reasoning', as might be expected when analysing the considered views of a British statesman. He admitted that he initially considered reading out Bethmann's message to the Commons, but explained that idea was 'deliberately discarded', because it 'would tend to stir indignation, and the House ought to come to its decision on grounds of weight, not of passion.' He also knew that, whenever the government did decide to publish the Chancellor's proposal, 'it would no doubt strengthen feeling. ${ }^{97}$ This presumably explains why Asquith exploited it in his own speech a few days later. The actual invasion of Belgium on 4

\footnotetext{
${ }^{94}$ Harcourt Journal, 26, 27 and 30 July.

${ }^{95}$ Crowe papers, Ms.Eng.d.2903, Eyre to Clema Crowe, 30 July.

${ }^{96}$ James, Memoirs, 20; Harcourt Journal, 2 August.

${ }^{97}$ Grey, Twenty-Five Years, II, 14-15.
} 
August could only deepen the despair over German behaviour. As late as 2 August, one Liberal backbencher 'could not believe that a liberal Government can be guilty of the crime of dragging us into this conflict', but a few days later he wrote: 'when Germany decided on an unprovoked attack upon Belgium, whose neutrality Germany equally with ourselves had guaranteed, it seemed impossible for us to stand by.' Birrell later asked, 'Can it be fairly said that we were wrong in the rage that an act, so significant of the temper of the German War Lords... raised in our breasts?'98

Looked at from an emotional perspective, then, the July Crisis may justify the argument of Valentine Chirol, former foreign correspondent of The Times, that Britain was moved, "not by a generous sense of our obligations... but by the inexorable pressure of Germany's open contempt of all our interests and susceptibilities. ${ }^{\text {'99 }}$ It is this that explains why the invasion of Belgium drove the British government to war on 4 August, when the hypothetical discussion of 29 July suggested that ministers might evade the 1839 guarantee. By 4 August the Belgian question was no longer a dry, legal one, but surrounded by rising anger at German aggression and fear of dishonour; indeed, it the marriage between supposed contractual obligation and moral outrage - of rationalism and emotion - made it the perfect cause for the British to declare war.

\section{Conclusion}

For Cabinet ministers the July Crisis was a searing experience. It could hardly be otherwise given the universality of emotions and their integral role in human decisionmaking, as well as the rapid development of the crisis, the pressure of meetings and

\footnotetext{
${ }^{98}$ David Dutton, ed., Odyssey of an Edwardian Liberal: the political diary of Richard Durning Holt (Gloucester: Alan Sutton, 1989), 33-4; Birrell, Things Past, 234.

${ }^{99}$ Cambridge University Library, Charles Hardinge papers, Vol. 93, Chirol to Hardinge, 4 August.
} 
the great issues at stake. As Masterman put it, 'It was a company of tired men who for twelve hot summer nights, without rest or relaxation, had devoted their energies to avert this thing... No one who has been through the experience... will ever be quite the same again. ${ }^{100}$ Ministers were themselves aware of the value of emotional appeals to M.P.s and the public; they made similar appeals to one another in terms of honour, duty, loyalty and courage; but they were also, each of them, subject to emotions as individuals. At a dinner 2 August, Ramsay Macdonald recognised that the varied emotions felt by three ministers might be more significant than the rational arguments they rehearsed: 'Masterman jingo, George ruffled, Simon broken. George harped on exposed French coasts \& Belgium but I gathered that excuses were being searched for.' ${ }^{101}$ Grey later acknowledged that, during the crisis, 'considerations worked in my mind by flashes of instinct... rather than by calm proofs of reasoning. ${ }^{102}$ Yet, in a century of study, historians have barely touched on the potential value of such an insight for re-interpreting the July Crisis.

The argument here is not that rational decision-making lacked importance or was somehow 'trumped' by emotionalism: careful discussion of British legal commitments clearly took up a significant amount of Cabinet debate. But rationalism operated alongside emotion and it can be difficult to separate them, especially when concepts like honour, loyalty and duty are raised. The Belgian guarantee and French entente, two issues at the centre of Cabinet debate, drew together questions of national interest, not least the security of the English Channel, and honour which, in the British sense, was tied to the fulfilment of contractual obligations. But a key argument here has been that honour, while a valuable route into grasping the importance of

\footnotetext{
${ }^{100}$ Lucy Masterman, C.F.G. Masterman: a biography (London: Nicholson and Watson, 1939), 266.

${ }^{101}$ MacDonald Papers, PRO30/69/1753/1, diary, 23 September.

${ }^{102}$ Grey, Twenty-Five Years, II, 15.
} 
emotions, does not draw out their full significance. There was also a rising level of anger - probably the most important single feeling driving Britain towards war - over German behaviour. In late July, most ministers were reluctant to risk war for France, while their initial, legalistic discussion of the 1839 guarantee failed to stir the blood. But strong feelings of anger, shame and betrayal were stirred by other issues, most important being Bethmann-Hollweg's cack-handed offer of a neutrality deal, which Grey recognised as having a primarily emotional impact. These paved the way for the situation in which Germany's actual invasion of Belgium allowed many former antiinterventionists, including Lloyd George, to approve Grey's 3 August Commons speech. A few still chose to resign, but they departed quietly, refusing to explain themselves in the Commons. The former Conservative premier, Arthur Balfour, graciously conceded that Asquith "managed his Party \& his Government with extreme dexterity ${ }^{103}$ and part of this management was a sound understanding of human emotions, as well as an almost ruthless ability to manipulate them: Asquith was cool under pressure, knew how to appeal to duty and readily welcomed back Beauchamp and Simon.

Emotions may be interpreted alongside more precise developments, as part of the 'march of events' that Churchill, on 31 July, predicted would carry Britain into war. ${ }^{104}$ They helped keep most of the Cabinet together, as reflected in Samuel's complaint that those who those who resigned 'have no right to abandon us at this crisis - it is a failure of courage. ${ }^{105}$ They also helped justify war, as with Grey's insistence in his speech 3 August speech that, 'If, in a crisis like this, we run away from those obligations of honour and interest as regards the Belgian Treaty, I doubt

\footnotetext{
${ }^{103}$ British Library, Arthur Balfour papers, Add.Mss. 49832, Balfour to Alice Balfour, 8 August.

${ }^{104}$ Churchill, ed., Companion, II, Part 3, 1987-88.

105 Wasserstein, Samuel, 164.
} 
whether, whatever material force we might have at the end, it would be very much value in the face of the respect that we should have lost. ${ }^{106}$ Rather than emotions somehow distorting rational decision-making for a short time, then, a look at their impact on British decision-making in 1914, confirms that they were constantly present, an integral part of reality, even if they affected different individuals in different ways and varied in their mix and force over time. It may be that individuals rationalised decisions, as they were culturally expected to do when, actually, they were at least as deeply affected by emotions, as suggested by Simon's search for excuses after his nerves failed over resignation. On some issues, not least reactions to the Bethmann-Hollweg proposal, the emotional reaction felt by politicians and officials seems to have been more significant than any rational response.

One serious problem for historians, in trying to trace the impact of emotions on past events, is that actors themselves may hide their feelings and prefer to portray themselves as acting for rational reasons. This is certainly a problem in the July Crisis. The telegrams and memoranda that reflect Foreign Office decision-making are almost always written in cold, objective tones and, even when one turns to more personal sources, such as the detailed diaries of Harcourt and Pease, it can be difficult to trace the emotions they felt as the crisis unfolded. Emotional evidence is thin on some of the nineteen Cabinet members, like Hobhouse and Masterman, even thinner on Birrell, Crewe and McKenna, totally absent on the Secretary for Scotland, McKinnon Wood. But the problem is not an insurmountable one and this article demonstrates that it is possible for historians of British foreign policy to factor emotions into their accounts. A range of emotions was on display, including sadness

${ }^{106}$ House of Commons Debates, Vol. 65, column 1823. 
and dismay over the decision for war, but with some of the strongest feelings being anger and betrayal over German behaviour, and loyalty and duty towards colleagues. The feelings of most ministers are betrayed to some extent in the written record, especially in personal sources like diaries, letters and memoirs, if only to demonstrate that a few, like Asquith, had excellent self-control while others, like Simon, became animated and unpredictable. It is possible to discern the bellicosity of Churchill, the changeability of Lloyd George and the increasing strain on Grey. Among the three ministers who resigned, one can compare Burns' agitated determination, Morley's pain and Trevelyan's single-mindedness. Viewed in this way, engagement with the 'emotional turn' may even reinforce traditional areas of international history, deepening an interest in individual biographies as revealed in the written record, while allowing old debates on a range of negotiations, relationships and crises to be refreshed. 